\title{
Democracy underwater: public participation, technical expertise, and climate infrastructure planning in New York City
}

\author{
Malcolm Araos $^{1}[$
}

Published online: 9 November 2021

() The Author(s), under exclusive licence to Springer Nature B.V. 2021

\begin{abstract}
This article provides an explanation for how increased public participation can paradoxically translate into limited democratic decision-making in urban settings. Recent sociological research shows how governments can control participatory forums to restrict the distribution of resources to poor neighborhoods or to advance private land development interests. Yet such explanations cannot account for the decoupling of participation from democratic decision-making in the case of planning for climate change, which expands the substantive topics and public funding decisions that involve urban residents. Through an in-depth case study of one of the largest coastal protection projects in the world and drawing on global scholarship on participation, this article narrates the social production of resistance to climate change infrastructure by showing how the state sidestepped public input and exercised authority through appeals to the rationality of technical expertise. After a lengthy participation process wherein participants reported satisfaction with how their input was included in designs, city officials switched decision-making styles and used expertise from engineers to render the publicly-supported plan unfeasible, while continuing to involve residents in the process. As a result, conflict arose between activists and public housing representatives, bitterly dividing the neighborhood over who could legitimately claim to represent the interests of the "frontline community." By documenting the experience of participants in the process before and after the switch in decision-making styles, this article advances a sociological description of public influence in policy: The ability for participants in a planning process to recognize their own input reflected in finished plans.
\end{abstract}

Keywords Climate change $\cdot$ Expertise $\cdot$ Participatory democracy $\cdot$ Public participation · Urban sociology

Malcolm Araos

malcolm.araos@nyu.edu

1 Department of Sociology, New York University, New York, NY 10001, USA 
Large portions of coastal cities around the world face the threat of being underwater. By 2050, climate scientists project that about 150 million people globally could be exposed to chronic flooding from human-induced sea level rise (IPCC, 2018; Kulp \& Strauss, 2019). In response, city governments in urban centers are experimenting with large scale flood infrastructure as a way of adapting in place (Oppenheimer et al., 2019), as well as contemplating the controversial possibility of retreating away from rising seas (Hino et al., 2017; Koslov, 2016; Siders, 2019). Scholars and policymakers alike have emphasized the importance of public participation in infrastructure plans, noting the desirability of including residents and other civil society actors to legitimize and bolster the procedural justice dimensions of government initiatives (Anguelovski et al., 2016; Oppenheimer et al., 2019; Shi et al., 2016). Yet a challenge for sociologists in the coming decades will be to understand the possible roles for residents, community groups, and the state in collectively preparing for our warmer, wetter future: How, and to what extent, should large-scale climate policy be guided by democratic principles, and to what it extent should it be guided by technical experts with specialized knowledge such as climate scientists or engineers?

Sociologists have long been interested in the tension between participatory democracy and technical expertise. Since the exchange between John Dewey (1927) and Walter Lippmann (1922) on this topic, scholars have sustained debate over the advantages and drawbacks of public influence in technical policy decisions for nearly a century (Eyal, 2019; Schudson, 2006). Curiously, for all the analytical energy spent debating arguments for and against, sociologists have produced little empirical research describing cases of democratic or technocratic decision-making styles for complex technical problems. Moreover, literature on this topic glosses over the precise mechanisms through which the state makes decisions and implicitly assumes that governments can easily 'turn a knob' to increase or decrease how technocratic or democratic their decision-making styles will be. In this context, key questions remain: How do governments attempt to implement participatory or technocratic decision-making styles, what are their effects, and what hurdles do they face?

This article explores these questions through an in-depth case study of the local politics of adapting New York City to climate change. The East Side Coastal Resilience (ESCR) Project, one of the world's largest and most expensive coastal protection projects, aims to rebuild a climate-resilient version of East River Park, a long, narrow, green stretch between FDR Drive and the East River in lower Manhattan. The goal, at the price of $\$ 1.45$ billion, is to raze and lift the current park by eight or ten feet to form a protective flood barrier. The new park would insulate the neighborhood from future sea level rise while remodeling the public amenity, and would represent the first phase of a planned total remake of Manhattan's coastline in the wake of 2012's Superstorm Sandy. Owing to the desires of high-profile architects to experiment with novel ways of designing flood infrastructure, and later, Mayor de Blasio's expressed commitment to public participation in city policy, the process of imagining the infrastructure project was to be "radically inclusive." During the first phase of the project's planning - the design phase - residents participated in intensive rounds of workshops, design charettes, and public hearings, and reported being satisfied with the process. Indeed, through what architects called an "iterative design 
process," participants continuously recognized their inputs reflected in the evolution of visual renderings and sketches for the infrastructure project.

However, a series of engineering reviews hidden from public view revealed intractable practical problems with the plan of public consensus, and the city abandoned the public plan for a new project they described as more "technically sound." The switch created a legitimacy crisis for city agencies, as the move to reject public input tainted the technical expertise of city staff as politically motivated in the eyes of a section of participants. In response, community groups and activists, angered at the lack of democratic input, destruction of trees and animal habitat, and temporary loss of a key public amenity, mobilized to paralyze the project's progress. Further, a bitter conflict emerged between those who valued a flawed plan that would still provide flood protection, and those who rejected the city's new decision-making style and the wholesale destruction of the park.

This study makes three theoretical contributions, each extending existing sociological literature to account for the contemporary condition of climate change in cities. First, for scholars of democracy, this study identifies a mechanism explaining the decoupling of public participation from democratic decision-making. Rather than focusing, as previous sociological research in the American context has, on how the state co-opts participation processes to advance private land development interests or restrict the redistribution of resources to poor urban neighborhoods (Levine, 2017; McQuarrie, 2013; Walker et al., 2015), the case study draws on global scholarship on urban studies and development to argue that the state can exercise power through appeals to the rationality of technical expertise. Specifically, in New York, city officials enrolled the expertise of professional engineers and climate scientists as a way of defining the window of what is possible and to render the publicly-supported plan unfeasible.

Second, the switch from a participatory decision-making style to a technocratic style within a single project provides a longitudinal dimension to compare the experience of participating in the planning process before and after. Building from observation of these experiences, this article advances an ethnographically-informed description of public influence in policy: The ability for participants in a planning process to recognize their own input reflected in plans. By taking seriously the motivations of participants for remaining involved in a process they found satisfactory before the switch to a technocratic style, this description departs from recent critical literature portraying public participation as inherently limited or destined to fail (McQuarrie, 2013; Walker et al., 2015), or undertaken under a false pretense to advance predetermined plans (Levine, 2017).

Third, for environmental sociologists this study questions conventional understandings of "frontline communities" as a spatially homogenous group of people (Agyeman et al., 2016; Bullard, 2018; Taylor, 2000). By documenting disagreements among residents and activists participating in the planning process, the case study shows that differences amongst the community exist along temporal lines - existing threats to existing environmental amenities versus future risks from climate impacts. This finding adds a temporal dimension to the established divisions between urban environmental groups prioritizing conservation and groups emphasizing environmental justice (Taylor, 2009). Older activists living in market housing prioritized 
their use of the park as a contributor to their everyday health and social connection, while public housing residents by the coast were willing to forego their short-term use of the park for long-term flood protection in the face of past and future impacts from climate change.

\section{Participatory democracy, technical expertise, and climate change}

The first legacy this study draws from is the sociological tradition of studying the practices of participatory democracy in urban settings. Public participation in politics refers to the direct involvement of citizens in decision-making processes rather than indirect involvement via voting (Schudson, 1999). Since the 1960's, social movements and government reforms institutionalized participation in low-income neighborhoods, a feature that in the last 20 years has become central to the logic of governing cities under the rubric of "public governance" (Baiocchi \& Ganuza, 2016). In the early 2000s, as scholars lamented the decline of civic participation (e.g. see Putnam, 2000), this new movement posited that expanding participation could be a source of democratic renewal, social solidarity, and decisions that the public would perceive as more legitimate. The goal of local participation is to produce democratic outcomes and empower citizens through incorporation of their unique knowledge into decision-making. The upshot of research from participation advocates is that direct involvement of citizens in decision-making can bolster procedural justice and, in practical terms, can reduce social and political resistance that could emerge if the government or another actor imposed a plan without public input.

However, recent sociological research in urban settings has presented a paradox: Increased participation has not necessarily resulted in increased decision-making power (Baiocchi \& Ganuza, 2016; Walker et al., 2015). Starting in the mid-twentieth century, sociological studies have documented the complicated relationship between participation and public policy (Moynihan, 1969; Selznick, 1953). More recent research is even more cynical, as scholars have documented how city officials can design public forums to elicit participation from the public in ways designed to decouple deliberation from decision-making power. While participatory technologies were once "used to challenge the authority of urban elites," Walker et al. (2015) explain, "they are now a central component of that authority."

The study of the tension between participatory democracy and expert knowledge - a tension that has troubled sociologists for nearly a century - may shed light on this paradox of "rising participation and declining democracy" (Walker et al., 2015). The debate over democracy and expertise began with Walter Lippmann's Public Opinion (1922), ${ }^{1}$ where he denied the "omnicompetence" of the public. In everyday

\footnotetext{
1 This article focuses on the role of engineers as technical experts in participatory democracy, but variations of this debate have focused on a range of substantive areas such as the role of intellectuals in public life (Bourdieu, 1989); expert testimony in courts of law (Golan, 2004); economists in development (Easterly, 2014); and the role of corporations in regulatory policymaking (Oreskes \& Conway, 2011), among others. The original Lippmann-Dewey debate was about the role of journalists in a democracy.
} 
decision-making, Lippmann argued, public officials should consider the views of experts rather than solely listen to voters, since the world is complex and people's ability to engage with issues is limited by their lack of expertise. John Dewey agreed that the public had little understanding of the political world. But for Dewey, experts, like all elite authorities, ultimately speak for their own interests rather than for the public interest, and they risk becoming an oligarchy if the public "do not have the chance to inform the experts as to their needs" (Dewey, 1927 quoted in Schudson, 2006). ${ }^{2}$ In present day, Eyal (2019) argues, we find ourselves amidst a crisis of expertise, which doubles as a crisis of democracy: Technical experts have largely lost the trust of the public to be the sole decision-makers after several high-profile incidents wherein experts miscalculated risk with dire consequences (e.g. Chernobyl or Fukushima). Yet at the same time, the modern world is fraught with potentially catastrophic risks that require specialized knowledge to address, or at least, to reach a decision within the time-frame demanded by the problem (Beck, 1992).

Development and urban studies scholars have also long documented tensions between experts and democracy in various empirical settings, often in the Global South. Easterly (2014), studying the World Bank's history in Africa, found that development experts routinely subvert rights and democracy in favor of technical solutions to poverty. The experts' solutions often involve advising authoritarian governments to implement top-down development schemes that do not alleviate poverty with the same effectiveness as bolstering rights and self-determination. Li and Zhong (2020), in an account of the remaking of Shanghai's waterfront, found that the local state claimed their plan was democratic because it was "for the people," but the plan was drawn up entirely by local leaders and planners, and sidelined the everyday users of the area. A number of other case studies ranging from participatory forestry in Guatemala (Millner et al., 2020) and Tanzania (Green \& Lund, 2015), to water supply management in Taiwan (Fan, 2016) and neighborhood planning in Philadelphia (Maskovsky, 2006), have similarly meditated on the complicated relationship between specialized knowledge and democracy. The conclusion of this research is that participation holds promise to promote procedural justice, but the government's tendency to wield authority based on expert advice rather than public input is a significant barrier towards achieving democratic decision-making for complex sociotechnical environmental issues (Ottinger, 2013; Pickering et al., 2020).

A similar tension between public participation and expert judgement exists in climate policy debates. In a landmark 2019 United Nations report on the effects of sea level rise, scholars praised public participation as a "decision tool" to reduce the polarizing effect of top-down new infrastructure projects in urban settings (Oppenheimer et al., 2019). The result, in theory, would be to "successfully include vulnerable groups in adaptation processes, promote justice, and enable transformative change" (Oppenheimer et al., 2019). On the other hand, since the 1970's, so-called "eco-authoritarians" have argued that "some aspects of democratic rule would have to be sacrificed in order to achieve sustainable future outcomes," (Held \& Hervey, 2013) and have called modern democracy an impediment to dealing with climate

\footnotetext{
${ }^{2}$ See Schudson (2006) for a more detailed retelling of this debate.
} 
change, since authoritarian regimes do not need to be attentive to citizen input to impose policies in key technical areas such as climate change (Heilbroner, 1974; Ophuls, 1977).

Advocates of participation promise that approaches mixing expert judgement with participatory input can produce both politically legitimate and technically sound decisions. Callon et al. (2009), for example, propose that "hybrid forums" composed of experts and laypeople can be productive sites of collaborative decision-making for complex environmental problems, such as decisions about nuclear waste disposal in France. Schudson (2006) alternatively suggests that experts can live up to democratic ideals when they use their technical judgement to support the public's interests and stand up to governments in the case of controversies. And Futrell (2003) found, in his study of chemical weapons disposal, that publicly-accepted and technically-safe decisions can be reached when the government collaborates with citizens, rather than when they lock them out of the process. Less hopeful scholars, however, argue that participatory approaches, if they are too open-ended and loosely formatted, will never produce a decision, let alone consensus. Legitimacy depends on the ability of bringing a controversy to an end, and participatory measures lack mechanisms for doing so (Eyal, 2019). Deliberation can go on forever, and in a participatory forum nobody has the authority to make a decision if consensus is not reached.

Curiously, American urban sociology has largely ignored the problem of technical expertise when explaining the paradox of rising participation and declining democracy in cities. McQuarrie (2013), for example, proposed that government officials in American cities have progressively narrowed the scope of what is up for discussion in participatory forums since the 1970s as part of a neoliberalizing reform of governance in urban areas, and so residents are relegated to deliberate on issues that are largely inconsequential to substantial distribution of resources in urban neighborhoods. More recently, Levine (2017) argued that government officials purposefully exploit the vague definition of "the community" to give residents the appearance of empowerment while retaining ultimate decision-making authority. City officials, in Levine's (2017) account, put decision-making in hands of "the community," but "the community" could mean a number of things, including land developers themselves, if for example, members of the development team live in the neighborhood. Both are accounts of elite authority sidestepping democratic decision-making to restrict the flow of funds to poor neighborhoods or to benefit real estate developers. Neither explanation emphasizes the role of technical experts in producing or legitimizing these decisions.

Existing urban sociological theory thus fails to explain what happened in the case of planning for climate change in New York, which expanded, not narrowed, the substantive topics that involve urban residents. Over the last decade, the city's political elite has voiced strong support for including residents' input in planning for the relatively novel challenge of climate change. In the case of the East Side Coastal Resiliency Project specifically, the switch to a technocratic decision-making style also made the project more expensive, thus distributing significantly more resources into the neighborhood. In the first phase of the project, the entirety of the design for the $\$ 1.45$ billion infrastructure project was self-consciously up for deliberation, and city officials explicitly gave any residents that came to public meetings 
the opportunity to directly design "community-driven" flood protection. But in the second phase, city officials sidestepped public input by building an argument that deferred to engineering concerns to render the public plan unfeasible.

The problem of future climate change impacts provides a unique case to study the decoupling of participation from democratic-decision making. In the case of planning for climate change, city officials rely on and leverage expert and professional knowledge systems about the future from engineers and climate scientists - knowledge that is not easily producible by or legible to most participants in the planning process - to shore up the legitimacy of their decisions. ${ }^{3}$ While the city elicited input from "lay experts" with unique knowledge about neighborhood conditions, with the explicit aim to be inclusive of anyone with a claim to expertise on the subject of neighborhood flood vulnerability and public space, ultimately the voice of credentialed technical expert professionals prevailed in designing the final version of the plan. The result was a legitimacy crisis that the government could not undo despite their repeated appeals to the objectivity and rationality of technical experts.

Finally, a feature of existing research on public participation is that analysts impose their own definition and evaluation of public influence in policy, and report their own assessment of whether participation is meaningful or not. In Arnstein's (1969) famous "ladder of participation" formulation, it is up to the analyst to evaluate whether the public's participation is impactful or symbolic, and the experiences and opinions of participants themselves are somewhat sidelined. Yet in cases where participation is designed as toothless from the start, why would anyone participate at all? Why would people be motivated to take part in a participation process that is designed to undermine their input? One common answer is that the public is naïve and does not recognize that participation processes are symbolic. The starting point for this case study is that this answer is unsatisfactory, and instead takes seriously the experience and perspective of people participating in the planning process to inductively theorize what motivates people to stay engaged in the planning process. The product is an ethnographically-informed description of what the public interprets as their influence in policy, defined as the recognition of one's own input in the evolution of city plans.

\section{Climate justice and community representation}

This study is also indebted to the pioneering research by Robert Bullard (2018) and subsequent environmental justice (EJ) scholars (see Agyeman et al., 2016 for a recent review), who documented how low income residents, often people of color, live with disproportionate pollution from industry in their neighborhoods and suffer

\footnotetext{
3 See Foucault's (1980) term "power/knowledge," arguing not that politics warps knowledge or rationality but that power and knowledge are inseparable from each other, and that the definition of a widely accepted truth is an effect of power. A variation on this argument about the social production of an accepted truth can be found in Navon and Eyal (2016), who propose that there are "networks of actors, devices, concepts, and institutional, discursive, and spatial arrangements that give the statement the value of truth-that make it thinkable, defensible, and actionable."
} 
higher rates of associated illnesses than high income and white residents. Climate change introduces new questions for scholars interested in such inequality in urban settings. While environmental injustice refers mainly to unequal exposure to industrial pollution, the concept is increasingly applied to unequal vulnerability to climate threats, at both the global and local levels. Globally, the countries most responsible for emitting carbon dioxide are best resourced to protect themselves, whereas nations with the lowest carbon footprints generally possess few resources to do so (Ciplet et al., 2015; Harlan et al., 2015; Roberts \& Parks, 2006). Locally, a similar pattern holds. In U.S. cities, poor neighborhoods such as the Lower East Side are typically more exposed to heat waves, more prone to catastrophic flooding, and more likely to experience morbidity and mortality during extreme events (de Sherbinin \& Bardy, 2015), even as residents in these neighborhoods are least responsible for urban carbon emissions (Rice et al., 2019; Wachsmuth et al., 2016).

Communities with greater economic and social capital are more effective at mobilizing against threatening efforts to site hazardous land uses nearby. In the case of climate justice, relatively privileged communities are able to collectively seek government or otherwise institutionally-backed support, such as protective infrastructure projects, to reduce their exposure and vulnerability to climate impacts (Agyeman et al., 2016; Schlosberg \& Collins, 2014). Adaptation infrastructure projects, from sea walls and stormwater storage basins to green roofs and urban parks, can make a difference in reducing vulnerability to climate impacts.

Environmental and climate justice research implicitly takes the existence of a spatially homogenous community affected by climate impacts as a given. Despite a number of theoretical orientations, as Auyero and Swistun (2008) note, most accounts of environmental justice movements share a classical Marxist model of consciousness, where "physically proximate aggrieved people overcome false beliefs or persistent uncertainties through reflection and interaction" (pg. 358). The outcome is almost always, in environmental justice accounts, a single and determined consensus regarding the problem and its solution, where the main and singular actor is "the community" (Auyero \& Swistun, 2008). Even in cases where communities paradoxically mobilize in favor of hazardous sites to be located nearby, such as community-supported fracking wells (Jerolmack \& Walker, 2018), or when communities are uncertain about where pollution comes from (Auyero \& Swistun, 2008), the unit of analysis is an entire community thought to face a common risk and hold a common interest in planning for the future. Yet this theory fails to explain what happened in Manhattan, where we can observe a shared and clear recognition of flood projections and damage from Sandy, but two conflicting views on how to plan for the future. The Lower East Side, as we will see below, is wholly exposed and vulnerable to catastrophic flooding and was severely impacted by Sandy, but two opposing movements mobilized in the neighborhood and both used the language and framing of environmental justice advance their argument: One movement of people supported the climate infrastructure project and another movement rejected it.

To explain the division among groups in the LES, this article proposes that divisions between community groups can be interpreted as conflicts over temporal scale - existing present-day use of environmental amenities versus protection from future climate risks. A few scholars have documented rifts within environmental justice 
movements, such as debates over what should be the scale of anti-hazardous waste activism in Alabama (Alley et al., 1995) or the implications of race and class as bases of identification in social movement organizing in South Africa (Checker, 2004). How the empirical reality of climate change can add a dimension of difference within environmental justice movements, manifesting as a rift of temporal scale, is comparatively overlooked.

The case study highlights how participants' opinions on the plan are patterned according to residential status related to class - living in public housing or market housing -, the type of activities they use the park for, and sometimes, though not always, race. Representatives of public housing residents living on the coast, mainly women of color, prioritized flood protection from the long-term impacts of climate change and to avoid a repeat of Sandy, while older and whiter environmental activists mobilized against the plan by emphasizing their daily use of the park, the conservation of its nature (trees and animal habitats), and expected negative sideeffects of construction. Both groups, however, framed their positions as informed by environmental justice concerns, as the activist groups recognized the symbolic capital associated with social justice and equity in Mayor de Blasio's New York. The activists' emphasis on maintenance of open green space for leisure and enjoyment is reminiscent of Taylor's (2016) account of the rise of the conservation movement in New York in the 18th and 19th centuries, wherein relatively well-off families pushed for more open green spaces for recreation, while worker movements advocated for health and sanitation protections from the city. The empirical reality of climate change, however, adds a temporal dimension to this old cleavage. Relatively well-off residents privilege existing open space for leisure, while residents of public housing, as we will see, prefer to emphasize the long-term health protections from flood infrastructure.

\section{Case selection, data, and methods: climate infrastructure and democratic controversy}

I arrive at this argument through a case study of the East Side Coastal Resiliency project in lower Manhattan. Data for this paper come from three years of participant observation, from March 2018 to February 2021, in the ESCR planning process. For this article I draw on city-led public meetings and hearings, community organization-led meetings, marches, protests, and other events convened under the auspice of the infrastructure project and the label of climate resilience more broadly. The article also draws on a snowball sample of in-depth interviews and informal conversations with public housing residents, tenant leaders, park and environmental activists, residents in market housing, urban planners and other staff in various city agencies and private firms, engineers, journalists, and consultants working on the project in varying capacities. I also collected and analyzed publicly-available reports and technical documents related to the project, as well as local and national news media articles dating back to the early stages of design in 2013.

Activists were often keen to spend time talking and being interviewed and they tended to view me, a graduate student interested in participation in planning, as 
sympathetic to their cause. They perceived that our personal politics aligned and assumed that we would be on the same side of the issue (opposition to the project), which may have led them to express their opinions more candidly. I found it slightly more challenging to access the opinions of public housing residents, since they were less frequent attendees of public events and could perceive me as an outsider - a non-resident of the neighborhood who appears white and attends a nearby private university. This may have affected the type of information that public housing residents revealed to me. Nonetheless, I believe being a native Spanish-speaker helped build rapport during events with Spanish-speaking participants, many living in public housing. This difference in access across groups highlights the importance of complementing information gathered through interviews with observations of how people act and speak in public events.

The Lower East Side (Fig. 1) is a dense neighborhood in downtown Manhattan built over an in-filled tidal marsh next to the East River. Originally settled by Lenape people before being displaced by Dutch colonizers, the LES has a history as an immigrant destination and developed in proximity to the financial district, producing one of the most racially and economically diverse neighborhoods in Manhattan. The shifting character of the neighborhood is evident in the mixed built environment: Public housing developments, tenement houses, and new luxury high-rise developments are anchored by a dense network of local community organizations addressing youth engagement, education, employment, and equity issues in the neighborhood. This neighborhood-level diversity, however, belies stark racial and economic segregation at the block scale. While the neighborhood has some of the highest rent

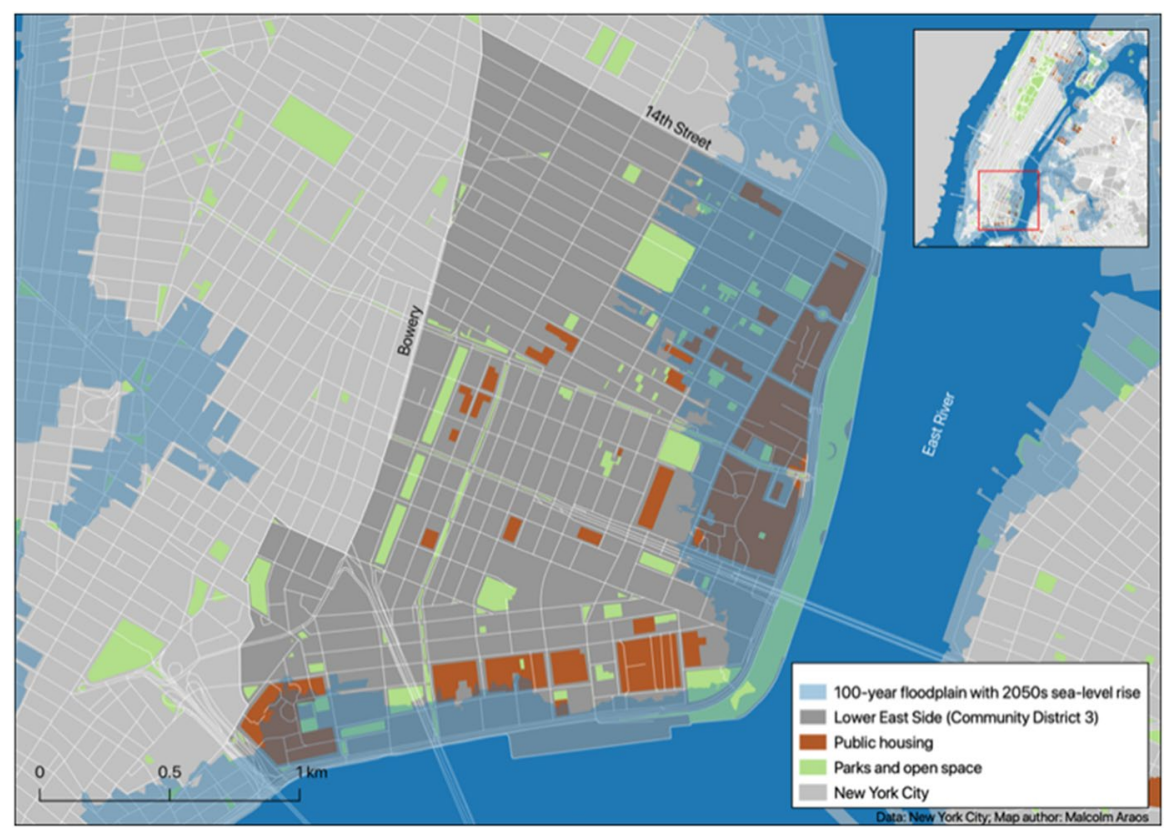

Fig. 1 Community District 3 in Manhattan 
prices in the city (around \$200 a month higher than the Manhattan average), median income is low and the rate of families below the poverty line is high $-27.3 \%$ of LES residents live below the poverty line compared to the Manhattan average of $16.2 \%$ (NYU Furman Center, 2018). Apartments in public housing account for 23\% of all rental units, housing more than 30,000 of the neighborhood's 163,277 residents. Over the last few decades, waves of luxury redevelopment have squeezed the availability of low-cost housing in the neighborhood. As a consequence, local activists and other residents have been left feeling besieged by Manhattan's real estate industry and distrustful of a city government they perceive as complicit (Brash, 2011). Superstorm Sandy disproportionately affected public housing residents, as a $13-\mathrm{ft}$ storm surge flooded the eastern blocks of the LES and nearby East Village, causing many buildings to lose electricity, heating, and hot water, in some cases for weeks. Beyond high-density housing, public institutions such as a cluster of hospitals, transportation and utility infrastructure, as well as small businesses were damaged and stopped functioning for weeks after Sandy, and today remain at risk in the low-elevation floodplain.

Post-Sandy New York presents a strategic case to study the social dimensions of adaptation to rising seas and more damaging storms. Sociologists have long shown how post-disaster situations can be leveraged as special opportunities for research, as the excessive circumstances they produce put underlying everyday power relations and social conditions into sharper relief than usual (Erikson, 1976; Klinenberg, 1999; Molotch, 1970). The claim dates back to the Durkheim school of sociology, as Marcel Mauss (1985) wrote that extremes are marked by "an excessiveness which allows us better to perceive the facts than in those places where, although no less essential, they still remain small-scale and involuted." Cities are particularly apt places to study the post-disaster process: A "great city," Robert Park (Park, 1915) wrote, "lay[s] bare to the public view in a massive manner all the human character and traits which are ordinarily obscured and suppressed in smaller communities."

As a neighborhood ravaged by disaster in a city spending billions to protect it from future catastrophe with the promise of input from its residents, the Lower East Side of Manhattan is not a typical neighborhood exposed to climate impacts. Yet this distinction is precisely what makes New York and the LES a powerful case study. As Zussman (2004) writes, "successful case studies look at extremes, unusual circumstances, and analytically clear examples, all of which are important not because they are representative but because they show a process or a problem in particularly clear relief." New York is a city with strong political willingness, tremendous resources, and an intention to democratize climate planning, representing a "pointy case" (Pacewicz, 2020) wherein the phenomenon of interest - the controversy between democratic decision-making and technical expertise in climate planning - is unusually pronounced. If New York's government faces problems pursuing democratic planning for climate impacts, it is likely that other less-resourced or lessparticipatorily inclined cities around the world may face similar difficulties, perhaps even in an exaggerated manner. Tensions between participation and technical expertise have been well-documented globally (e.g. Easterly, 2014; Li \& Zhong, 2020), giving us reason to believe that in other cities around the world, governments are likely to wield authority relying on technical expertise, with negative impacts on the 
procedural justice dimensions of climate adaptation and potentially creating resistance to large-scale projects. While we can expect that the specific empirical findings presented in this article will not appear in the same way across all other contexts, the controversies over climate infrastructure in New York show us generalizable social processes, as well as particular conditions under which these processes are likely to arise.

\section{The birth of the East Side Coastal Resiliency Project}

Superstorm Sandy in 2012 claimed the lives of 44 people, caused $\$ 33$ billion in economic damages, and disproportionately cut off power, heat, and hot water to public housing (Graham et al., 2016; New York City Mayor's Office, 2019; Schmeltz et al., 2013), As a response, the city triggered a long-term strategy to adapt its infrastructure - built in the twentieth century under the assumption of a stable climate - to future climate change impacts. The two mayors in office since the storm have committed to a vision of the city rebuilt stronger and tougher (New York City Mayor's Office, 2019). Since then, the rhetoric of climate resilience has dominated New York climate politics. Mayor Bloomberg's office rolled out over 200 initiatives under the label of resilience at a total price tag of nearly \$20 billion (New York City Mayor's Office, 2019), making New York the global leader in both spending (Georgeson et al., 2016) and number of planned initiatives (Araos et al., 2016) to protect itself from climate impacts. At a 2013 press conference unveiling the city's first flagship climate planning document, Mayor Bloomberg articulated his particular definition of resilience as armoring up the coast: "As New Yorkers we cannot abandon our waterfront [...] we must protect it, not retreat from it." Since Bill de Blasio's election, the new mayor maintained the same approach, while reframing all resilience initiatives through a "justice and equity" lens, reflecting his self-proclaimed emphasis on social justice (New York City Mayor's Office, 2019). While Brash (2011) characterized Bloomberg's mayoralty ending in 2013 as containing a deep technocratic streak, the process of rebuilding after Sandy and the subsequent mayor's administration centered public input in decision-making.

The East Side Coastal Resiliency Project is the first piece to be built as one of the world's largest and most expensive coastal protection projects- the project to remake the Manhattan shoreline in Sandy's wake. In 2013, the Obama Administration's Hurricane Sandy Rebuilding Task Force initiated Rebuild By Design, a first-of-its-kind design competition to fund proposals for infrastructure projects that would protect New York from future storms and sea level rise. Led by Housing and Urban Development, the Rockefeller Foundation, and a number of local research institutes, the New York metropolitan area was awarded \$1 billion to build seven projects, one of which was the BIG U, the conceptual predecessor to the ESCR (Klinenberg, 2018).

In 2013, the Danish design firm the Bjarke Ingels Group (BIG) joined the Rebuild By Design competition and carried out a collaborative, iterative, and stakeholder-intensive process, combining high-profile starchitect-led design expertise with an inclusive effort at community engagement in lower Manhattan. After a year-long design process, BIG designers and neighborhood groups agreed on a 
plan to redesign the Manhattan coastline to absorb floodwaters during storm surges, protecting the neighborhood from a 1-in-100 year storm such as Sandy, relying on a series of protective walls that double as sloped parkland and recreational facilities such as walkways and sports fields. According to a BIG designer, participants overwhelmingly chose vulnerability-reducing and green-planted berms on the inside edge of the park that also increased neighborhood access to the water while protecting public housing, building a natural buffer that would absorb storm surges. A key feature of this design was the maintenance of existing trees and shrubs in the park - the use of natural infrastructure for protection as a sponge in the event of major coastal storms - rather than destroying and rebuilding the public amenity entirely. This proposal constituted an intentional departure from typical seawalls, that is, high riverside floodwalls that cut the neighborhood off from the waterfront (Collier et al., 2016), an option an architect described as a "big dumb wall" (Goodell, 2016). Designers dubbed the resulting concept the "BIG U," referencing both the architecture firm's namesake and the U-shape of the lower Manhattan coastal tip. The proposal garnered significant international praise from the design and climate policy communities, as boosters highlighted both the collaborative design process and the natural infrastructure approach to protect the coast.

In 2014, the BIG U made its way from architectural concept into a concrete project that the city would fund and build. The city divided the project into different compartments to be built in phases along the Manhattan coastline. The first phase would be built on the east side of lower Manhattan, partly as a response to the damaging flooding that affected public housing residents in the LES during Sandy. The East Side Coastal Resiliency Project, as it was named, would redevelop East River Park based on intensive collaboration with LES neighborhood residents. From 2015 to early 2018, city agencies continued the participation and collaborative design process that BIG started, and by 2018, the self-described "radically inclusive" plan was ready to go into the city's land use planning process (see DuPuis \& Greenberg, 2019 for a detailed timeline of the process).

\section{Recognizing one's own input: participation with influence}

How did people experience the process of participating in the design of the ESCR Project? Throughout the first phase of the project, the design phase, participants reported satisfaction with the planning process, as they could see their own input reflected in the evolution of city plans. Catalina, ${ }^{4}$ a decades-long activist of Puerto Rican descent, summarized the process while sitting in her office at a nonprofit dedicated to help low-income residents find affordable housing in the LES. She said: "Designers and other folks would come with preliminary designs and ask the community a bunch of questions." She then highlighted the iterative process that went

\footnotetext{
${ }^{4}$ Individuals speaking in public events are identified by their real name, as per ethical considerations raised in Jerolmack and Murphy (2019) and Murphy et al. (2021); individuals speaking in private interviews are assigned pseudonyms.
} 
on after the first design sketch: "Then they [the designers] would come back again and present how they took that feedback and put it into the plan, then ask even more questions."

Similarly, at a summer 2019 public hearing, Naomi, a white middle aged activist, recounted her experience participating in the design phase, now as a representative of a group of local park conservation advocates. Speaking to a crowd of about 80 people in an event room of a community center in the LES, she also emphasized the iterative design process of the first phase of the project: "[T] he community engagement was really highlighted as key to the process, and we heard again and again the importance of what they called iterative design, that they listened to communities and incorporated them, tinker with design, re-think it, and bring it back to the community." Naomi's and Catalina's statements are typical, illustrating the view of participants that the iterative, repetitive process allowed them to view their own input reflected in city plans. Designers and planners would repeatedly come back to the neighborhood and show, through an evolution of architectural sketches and diagrams, that their input had been considered and included in official plans.

Beyond the mechanisms of the process, substantive questions about what flood protection for the neighborhood should look like, and tradeoffs about what to spend limited funding on were also seen as up for deliberation. Within funding constraints and supported by professional landscape architects, participants were able to discuss design alternatives among themselves. At the same meeting, Naomi reconstructed how the iterative design process of the Rebuild By Design competition shaped the expectations of activists on small and big issues, noting the open-endedness of the public deliberations in the style heralded by Habermasian ${ }^{5}$ democratic theorists:

"And it was more than just a process to think about park programming, it was also a conversation about resiliency. So more than just how to re-design our 1939 Robert Moses park, and where to put playgrounds, and ballfields, and barbeque pits. But also to think about where should the flood protection be, and how should it work [...] So those were the expectations of that process."

The input of participants is visible in scanned documents, pictures, and public reports from meetings and workshops produced during the design phase. A report of findings from a workshop in July 2015, for example, shows a large paper map of East River Park and depicts how workshop participants pasted post-it notes and wrote comments on the map. On the topic of "improving access to the park," participants expressed, on colored post-it notes: "safe and inviting access to East River Park is the community's number one priority," "ensure entrances remain wheelchair accessible," and "Build a new bridge at Grand Street and rehabilitate the Delancey Street bridge!" Four months later, in September, staff from the Mayor's Office of Resilience presented a number of alternative designs of several different entrances to the park and sought the opinions of participants about which ones were preferred. A month after that, the official design included new park access points that reflected

\footnotetext{
5 Habermas (1974), through his concept of the "public sphere," suggested that opportunities for public discussion can engender open-ended deliberations over how to reach toward public good.
} 
the input of participants. People involved in these workshops and meetings reported to be satisfied by how the city was carrying out the process.

Paula, a white-middle aged consultant working in a leadership position since the birth of the ESCR Project, described to me what she viewed as the atmosphere consensus surrounding the plan: "I think that this plan was like sliding through with A+ marks. I really do. [...] In fact, I was trying to get people to disrupt meetings because I thought the city was giving really lame excuses of why the benches had to be like park benches from the 1964 New York World's Fair and lighting that had to look like that instead of Brooklyn Bridge Park or the backend in Governor's Island, and people just went along with it." Paula recounted that the plan was uncontroversial, and that when residents now talk about the old plan, they call it the "consensus plan."

Nonetheless, people I spoke with often reported feeling conflicted about the potential negative impacts that the project could bring to the neighborhood. In particular, people worried that the flood protection and new park could increase the value of real estate properties in the floodplain, leading to further gentrification in the LES and displacement of low-income households, ultimately benefiting real estate developers rather than long-time residents. Ana, a middle-aged woman of Puerto Rican descent working in a nonprofit in the field of emergency preparedness, grew up in LES public housing and was involved throughout the process of designing the ESCR. When we met in her midtown office in early summer of 2018, before the switch, she told me about the many summer afternoons she spent barbecuing in the park while growing up and then with her own children in recent years. When I asked her how she viewed the ESCR project before the city changed plans, she was supportive of the flood protection, but also said: "I still think with the BIG U that I sold out my community. Because of the beautifying that it would bring." Ana was referring to a type of "green gentrification," wherein investments in park amenities, or "beautification," are associated with gentrification (Anguelovski et al., 2016; Gould \& Lewis, 2018). More recently, Keenan et al. (2018), have theorized that public investments in coastal protection infrastructure could similarly raise property values: An effect of having protected buildings is that they become more desirable, thereby becoming more expensive as well.

During my conversation with Ana in the summer of 2018, she was concerned that the plan would further rise rents in the neighborhood, but she did not bring up any complaints about how participation was carried out in the planning process. Indeed, during my observations in local meetings in early 2018, participants amiably discussed varying options for designing streetlamps, benches, or playground slides - deciding on the final touches of a plan that participants and the city largely agreed on. However, worries about gentrification became only one aspect of activists' many concerns after the city changed the plan in late 2018. In this first period of the project before 2018, the design phase, we have seen how the city's plan was legitimate in the eyes of neighborhood residents. This legitimacy drew on participants' ability to see their influence in the plan, in other words, the plan was only legitimate because participants were able to recognize their own input incorporated into the evolution of the plan. Once the city changed plans and this influence from the public vanished, the city sought to recreate the legitimacy of the project in other 
ways, namely by appealing to the objectivity and rationality of civil engineering processes and the threat of future climate change impacts. However, the city's rejection of the public plan tarnished the political reputation of government officials, which rendered their appeals to technical knowledge systems suspect in the eyes of participants, and ultimately failed to undo the legitimacy crisis that city officials had created for themselves.

\section{Legitimacy crisis: participation without influence}

In September 2018, near the 6th year anniversary of Sandy, the Mayor's Office announced a new design for the ESCR based on internal reviews by the city's own agencies without collaborating with either private design firms or the public's input. During a Community Board Parks Committee meeting, on a late September evening after several months of silence, city officials from the Department of Design and Construction (DDC) and the Parks Department presented a plan drastically different than the previous plan of public consensus. The new proposal moved far from the original BIG design that had gone through years of collaborative processes, and did away with the inland berms and the idea of a park as a sponge designed to absorb floodwaters (see Figs. 2 and 3). Instead, it will be built around a dirt fill, raising the current park and rebuilding the park on top of this fill. Rather than the sponge-like storm-surge-absorbing soft slopes, the project would involve traditional hard seawalls near the river supporting the several feet of fill. The new project is also budgeted at $\$ 700$ million dollars more than the original plan, lifting not only the park by around 8 or $10 \mathrm{ft}$, but also the price tag to $\$ 1.45$ billion. This change sparked public outrage and confusion at the notion of getting extensive public input and then building a different, more expensive project.

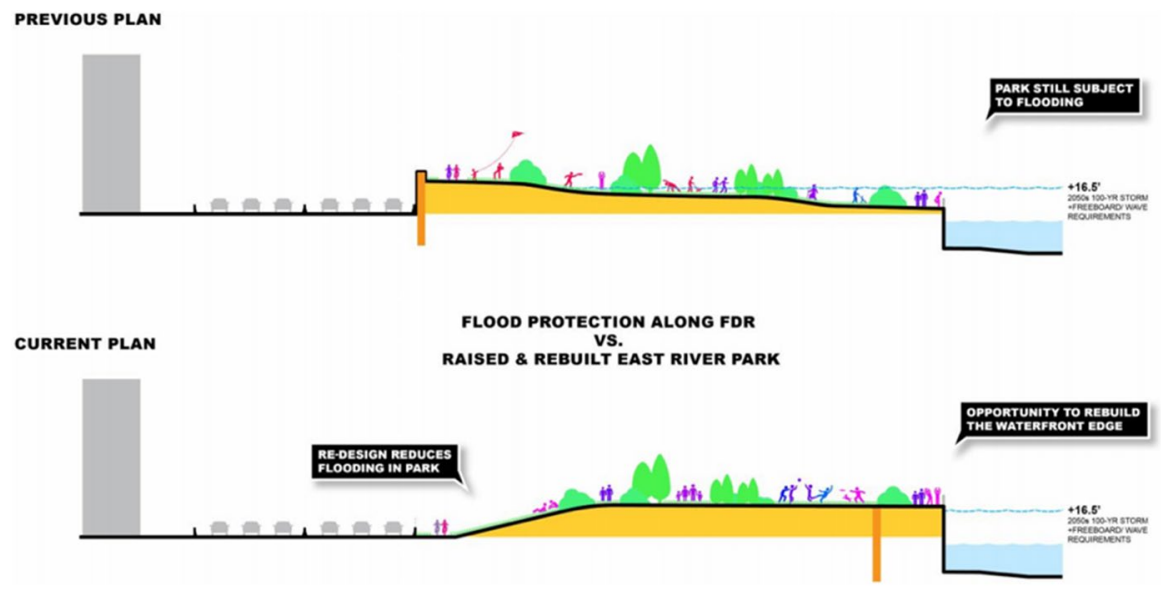

Fig. 2 Schematic cross-section illustrating difference between previous plan and current plan. Source: "Interactive Community Engagement Meeting" at Gouverneur Health on December 10, 2018 

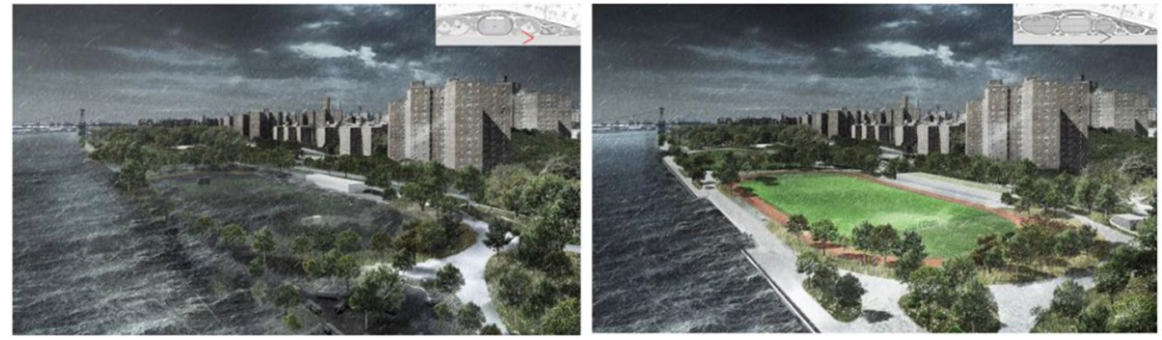

Fig. 3 Hypothetical storm conditions illustrating differences in flooding between previous plan (left) and current plan (right). Source: "Interactive Community Engagement Meeting" at Gouverneur Health on December 10, 2018

What was the explanation for the plan change in September 2018? Participants frequently said they saw the change as a lightning bolt coming from nowhere. In a public interview, long-time activist Damaris Reyes said: "Right before the plan went into the city's Uniform Land Use Review Procedure (ULURP), everything stopped. Everyone went quiet. And in September they came out with a totally different plan and everyone went crazy." Activists and residents (and sociologists) could not peek into the black box of decision-making to observe precise moment that the plan changed. In the years since the change of plans, activists insisted on requesting the engineering documentation that justified the change of plans. City officials, until late 2020, responded that no single document explaining the changes existed, and instead resorted to justifying the change with presentations at public meetings.

Two official explanations were put forth, one from DDC and another from the Department of Parks \& Recreation. Jamie Torres-Springer, a white middle-aged Deputy Commissioner of DDC, explained to a crowd in early summer of 2019 that about 6 or 7 months previously a number of engineering reviews looked at whether DDC could deliver the plan. DDC is responsible for the construction of the project. Torres-Springer holds a Master's degree in public policy from Harvard University and was wearing business-casual attire. "And look," he said, "this is hard stuff, there have been engineers from all around the world that have looked at this challenge, and it took a while." Upon close inspection, engineers found a number of problems with the public plan. First, to build a structural wall on the western, inside part of the park, DDC would have to work with "big powerlines," ConEdison utility lines, under the area where the concrete edge was supposed to go (see the concrete wall represented as a dark orange edge in the old plan in Fig. 1), making construction a delicate affair and potentially extending the timeline of the project. Second, DDC would have to build the wall adjacent to the FDR. The Deputy Commissioner explained: "And not that we're all about cars all the time, but to ensure safety when you're building a structural flood wall, you can't have cars passing by overhead. And you have to close portions of the highway. And to prevent cars from using that portion of the highway and getting into the neighborhood, we had to do that work at night." The Deputy Commissioner stated that the construction period would then entail four years of nighttime work next to the FDR, where contractors would have to be driving piles into the ground. He finished his explanation by saying: "So okay, 
we would have had to drive this floodwall into the ground, next to where people were living, adjacent to the FDR, in the middle of the night, every night for four years. We came to the conclusion that that wasn't gonna work."

Parks \& Recreation had separate concerns, summarized by Torres-Springer in the same meeting. In the previous plan, "the park was really sacrificial, it was gonna flood if we had that 100-year storm." He expressed Parks' concern that the park would be increasingly lost to the community, as he went on: "We're going to see with sea level rise, tidal inundation, where on a monthly or sometimes daily basis, you would see water coming over that coastal edge and flooding the park." Another senior Parks official told me that the agency is not opposed to the approach of using parks as sponges, in theory, "but in New York we don't have the budget for maintenance right now." Yet another senior consultant on the ESCR told me a similar story: As the park increasingly floods, trees will be lost and will have to ripped out, and the park will have to remain closed while repairs take place, all at a recurring high expense for the Parks Department.

Eventually, in late 2020, the East River Park Action advocacy group filed a Freedom of Information Law request to retrieve the engineering reviews that would supposedly justify the new plan. On the first request, the city restated that no such document existed. Upon insistence, the city released a report titled "Value Engineering Report," which purported to explain the engineering rationale for the change. However, the document was almost entirely redacted with black ink obscuring the substantive text and images, purportedly due to national security reasons. Finally, after further public uproar and pressure from local councilwoman Carlina Rivera, the city published a mostly unredacted engineering study in early 2021 . The document reported on a series of meetings held by various city engineering agencies along with outside engineering consultants. The report summarized how engineers pored over technical challenges in closed-door conference rooms to optimize cost-benefit calculations, and concluded to abandon the public plan and produce a simpler design. With the new plan, the cumbersome ConEd utility lines would not have to be moved (corroborating Torres-Springer's story) and the project would end up being cheaper. In a section of the report outlining next steps, engineers recommended only one public-facing action: "Public updates will be needed" (City of New York Office of Budget and Management, 2018). The experts, then, not only severely underestimated the strong public response to their actions, but in documentation they barely considered how the public would react at all.

In public statements after 2018, Jainey Bavishi, Director of the Mayor's Office of Resiliency and the city's most senior resilience official, worked to distance the new ESCR Project from the old. She noted that the previous plan amounted to a design concept and was never intended to actually be built and was never deemed feasible. World-leading architects and designers came up with a novel approach to resilience infrastructure, she argued, but never considered crucial engineering problems that could arise and put the project in peril. Sitting next to Mayor de Blasio at a press conference in March 2019, she said: "I think it's important to realize that the BIG U was a concept. The BIG U has inspired the East Side Coastal Resiliency Project. The city has moved forward with planning and engineering analyses for this project. This project that we're presenting now takes that conversation forward and 
proposes projects that we can actually implement." Two months later she repeated a similar thought at a public conference in a glass-walled conference room in lower Manhattan, differentiating between public works and private design concepts ${ }^{6}$ : "it's important to keep in mind that this [the old ESCR] was not a city concept, but rather a concept developed by a private firm, the Bjarke Ingels Group. This project [...] ultimately helped us secure funding for the ESCR Project." Both statements appear to conflict with the official timeline of the plans and the experience of everyone involved: the East Side Coastal Resiliency Project existed with this name since early 2015, and the participatory design process continued for three years afterward.

The change of plan sparked protests, marches, the creation of new civic associations united in opposition to the new plan, two lawsuits from park advocacy groups, and changed the tone of every public meeting about the ESCR after September 2018. At a protest in East River Park in late 2019, Howard, a white middleaged activist, stood before the crowd and asked into a microphone: "What do we call a climate plan that will bulldoze our park and bury it under eight or ten feet of dirt, while ripping up a thousand trees and keeping the cars on the highway?" After nobody filled his expectant pause he offered his own answer: "A stupid plan!" Two new neighborhood groups, East River Alliance and East River Park Action, formed to organize events and mobilize activists in opposition to new plan. The Councilwoman representing Community District 3, Carlina Rivera, and Manhattan Borough President Gale Brewer both withdrew their support for the plan for the first few months. The first breaking of ground in East River Park was supposed to take place in the early autumn of 2019, but continues to be delayed into late spring 2021 at the time of writing.

The substance of what was up for debate in the new plan was also different than before. Take the following example: At a public hearing in early summer of 2019 , a white woman in her 30's asked city officials about visual connectivity from the neighborhood to the East River. "There's a lot of places now in the LES and East Village, where you can see the park and the river," she said, "so I'm picturing... if the park is 8 feet higher, will we be looking at the wall? And are there ways that you're going to pull the park into the city, so that those who are not using the park on a daily basis nevertheless feel drawn into it?" As described above, the issue of park access points and visual connectivity was previously up for deliberation. Now, Jamie Torres-Springer, the DDC Deputy Commissioner, responded in a way that acknowledged her concern while invoking long-term climate change as a reason to legitimize the current plan:

"The way I'd ask people to think about it is that we're dealing with climate change, and we have our waterfront edge, and sometimes there's a conflict. We see this in cities across the country, where you have people who really want to see the water all the time, but then we are realizing that that's actually a threat to us."

\footnotetext{
${ }^{6}$ See Fleming, 2019 for an analysis of tensions between large-scale public works and urban design competitions, using the BIG $\mathrm{U}$ as an example
} 
At another meeting earlier in the year, an attendee asked a similar question and received a similar answer. "We need to acknowledge that we're entering a very different era of living in waterfront cities," said the Deputy Commissioner. As a result, participants who remained involved in the process increasingly felt that decisions had already been made, that their input was now symbolic, and that they would not see their contributions reflected in how the plans evolved.

The city, then, sought to justify its new plan through a public demonstration of the technical soundness of the new plan and contrasting it to the unfeasibility of the old plan. The explanation of the engineering concerns was meant to indicate that the city's decision to propose a new plan had not been shaped by illegitimate interests. Indeed, activists regularly accused city agencies of changing plans for political reasons. At every meeting, participants voiced their suspicions that the city's primary interest in insulating the neighborhood from climate impacts was to raise land prices and benefit real estate developers, even by possibly selling parkland to private investors. "Based on the mayor's track record" said a middle-aged white resident at a meeting in summer 2019, "he wants to see tall buildings. So what assurances do we have that the mayor is not gonna come along and put up big sticks in the park?"

The politics of land redevelopment are contentious in the Lower East Side, so it was no surprise that activists and other residents consistently raised this issue in interviews and in public meetings. At the time of the ESCR controversy, many of the same activists resisting the project were also involved in mobilizing against the approval and construction of supertall luxury housing buildings in Two Bridges, a small pocket on the southern end of the Lower East Side. Throughout 2019 and 2020 , protesters gathered in the shade of brand new glass and steel residential towers to voice their discontent at the dwindling availability of affordable housing in the neighborhood, especially for long-time residents of nearby Chinatown (Ngu, 2019). Yet the fight against luxury housing in Two Bridges was only the most recent land development concern for activists. Many people involved in neighborhood politics have been scarred by their involvement in the planning for Essex Crossing on the north end of the LES - a four decade-long struggle among community groups, city agencies, and real estate developers to produce a mixed-use mega-development balancing affordable units with high-end apartments and businesses (Kimmelman, 2019). A simmering suspicion of the city's long-term re-zoning strategy, which advocacy groups claim will further tighten a perilously small supply of affordable supply in neighborhoods such as East Harlem and Sunset Park, also fueled activists' distrust of city officials.

In response to scepticism that the project was a ploy for the mayor to put up "big sticks" - a moniker for the supertall luxury residential skyscrapers going up elsewhere in the neighborhood - the city saw it as essential to appeal to the objectivity of engineering to regain its legitimate authority. Max Weber (2004) contended that the authority of bureaucratic agencies is based on their perceived objectivity, so it was essential for New York city agencies to distance themselves from political motivations: "Bureaucracy," Weber wrote, "develops the more perfectly, the more it is 'dehumanized,' the more completely it succeeds in eliminating from official business love, hatred, and all purely personal, irrational, and emotional elements which escape calculation." The city's leaning on technical 
experts was meant to approach this ideal of bureaucratic objectivity, to distance itself from politics, and to regain its authority. As Theodore Porter (1996) argues, bureaucratic agencies are expected to show "mechanical objectivity," and so to avoid seeming biased, "expertise should be mechanized and objectified. It should be grounded in specific techniques sanctioned by a body of specialists." Moreover, this mechanical objectivity, Porter argues, is especially important for weak agencies in controversial situations that must demonstrate the objectivity of how they make decisions: "objectivity lends authority to officials who have very little of their own" (see also Lakoff \& Klinenberg, 2010 for another example of the difficult entanglement between politics and mechanical objectivity). But the city's appeals to objectivity were not convincing in indicating their adherence to rationality over politics in the eyes of the public, since the professional relations of civil engineers, consultants, and climate scientists with city agencies tainted their technical expertise.

Residents continued to perceive the change of plans as politically motivated and became increasingly frustrated with the experience of continued participation in the planning process after the city's change of plans. In contrast to the experience of participating in the design phase of the project, people providing input in workshops and public hearings now could not see their input reflected in the evolution of the plans. At each meeting, city officials would repeat their technical justification of the new plan. They would continue to gather feedback, but this feedback rarely if ever made it into the plan. Participants perceived that their involvement was now without influence and it frustrated them. City officials, on the other hand, insisted that the process remained participatory, since residents continued to attend and provide feedback in city-organized hearings and meetings. Political legitimacy in the ESCR, then, came from residents participating in the process recognizing their own input in plans, rather than outside actors - such as city staff or researchers - imposing their evaluation of whether the participation process was meaningful or not. This understanding of influence is distinct from Arnstein's (1969) classic conceptualization of meaningful participation as an objective quality that exists outside the experience of participants involved in a planning process.

In response to the loss of legitimacy, the city doubled down on its appeals to technical experts, and in one such move hired a Dutch consulting firm specialized in flood management planning, Deltares, to perform an independent review and publish a report with the findings. With a few caveats, Deltares backed the city's decision to go with a new plan. Yet shortly before the publication of the independent report, activists discovered that the city had hired Deltares as a consultant for an infrastructure projected elsewhere in Manhattan, and so the firm's technical advice became tarnished by the suspicion of underlying financial motivations: In the view of activists, Deltares supported the city's plan in an informal exchange for the future award of contracts. Thus with every move the city made to continue appealing to technical experts, they only became more mired in suspicions of dishonest political motivations, and were unable to extricate themselves from the legitimacy crisis they had created.

As I describe in the following section, the city's move away from the original plan not only damaged the legitimacy of the project in the public's view, but also 
created a rift between different groups in the neighborhood. After spending four years developing a plan that reflected a public consensus, with the goal of promoting solidarity among people with different interests and visions of a resilient future for the neighborhood, the city undermined their own efforts through the new plan, as conflict emerged between older white activists and residents of public housing by the river.

\section{"Nobody speaks for us but us:" community representation and climate justice}

Environmental sociologists have long documented a rift between different types of urban environmental movements, namely between conservation movements where relatively wealthier and whiter groups prioritize the restoration and maintenance of urban nature, and environmental justice movements working to remedy inequitable distributions of urban pollution, hazardous waste, and health conditions for urban workers (Taylor, 2009, 2016). In the Lower East Side, this old division emerged to produce conflict among residents, but with an added dimension. A rift in the temporal horizons of present day risks versus future climate change, working as a new feature of the old division between conservation and environmental justice, came to characterize a bitter divide in the neighborhood. While representatives of public housing residents by the coast explicitly prioritized long-term protection from future floods and sea level rise, older white activist leaders highlighted their present-day use of environmental amenities - composting facilities, existing vegetation and animal habitats, and leisure space - as reasons why they resisted the project.

The visibility of activists could give the impression that all LES residents oppose the plan. This impression is understandable, since most vocalized or written responses to the plan were negative (e.g. see public comments submitted to the project's Environmental Review Statement [NYC Parks and Budget Office, 2019]). To be clear, almost everyone in the neighborhood participating in the process viewed the city's change of plans as a blow to the legitimacy of the project. Yet as I spent more time in the neighborhood, I began learning that a group of repeat-players were the loudest voices against the new plan. These individuals, often middle-aged, white leaders of community-based organizations and long-time activists, implicitly presented their views as representative of the neighborhood and frequently made references to "the community" as a homogenous unit. In the Lower East Side, it was activists, mostly white, who purported to speak for the interests of the entire community, including public housing residents.

Nonetheless, in every meeting some people advocated for flood protection, namely residents of public housing and the Resident Association presidents that formally represented them. Although angry about what they perceived as the city's switch to a technocratic decision-making style, these residents preferred a flawed plan to no flood protection. They prioritized security over other issues such as keeping the park open for recreation during the construction period. Residents emphasized their spatial location in the neighborhood and self-identified low-status as residents of waterfront public housing to anchor their priorities, 
often narrating their experiences during Sandy and invoking their current exposure to storms. They did not purport to represent "the community," as activists opposing the plan often did.

Throughout public meetings in early 2019, Resident Association (RA) presidents from public housing developments by the river routinely appeared to speak in favor of the new plan and highlighted its long-term outlook as a key benefit. At one meeting, Nancy Ortiz, president of Vladeck Houses Resident Association, responded to the activists expressing this concern in an angered tone and defended her prioritization of flood protection:

"The softball fields and tennis courts were closed on FDR drive for 5.5 years when they got renovated, nobody gave a hoot where our kids were playing, nobody cared that our kids did not have access to that area. We don't care that there's a 3.5 year, 4 year, closure. Why? Because that's a drop in the bucket for a hundred years of protection to the 20,000 individuals who live in the New York City Housing Authority [public housing]. Nobody speaks for us, but us, thank you."

In Nancy's view as representative of public housing residents, it is desirable to trade a park closure of a few years in exchange for 100 years of protection from climate changed storms and sea level rise. She went on to note that when small parts of the park closed in the past, affecting the recreation activities of mostly public housing residents, activists did not mobilize on their behalf, and so she asked that activists do not speak for her or for residents of public housing by the river.

Moreover, RA presidents never invoked "the community" as the unit they were representing. Instead they frequently highlighted that their constituency specifically comprises residents of public housing. At an early 2019 meeting, Camille Napoleon, a resident association vice-president, explained what she viewed as the priorities of residents in her development, not the community at large. She highlighted that avoiding a future disaster similar to Sandy was the foremost priority for her residents, and the rest of the issues regarding the plan could be negotiated:

"I represent Baruch Houses and we are the largest development citywide. I have a population of 5,096 residents right now. Listen, we are concerned with safety, with what we went through with Sandy. As long as this park considers its number one priority as safety, we can work the rest out. Right now we are in agreeance with this plan. The Tenants Association agrees with the current plan. As long as safety for my development and all those along the river is the number one priority."

Camille went on to use her experience with Hurricane Sandy to urgently prioritize the need for future flood security above other concerns, referencing potential events that could reprise Sandy's devastation. In her account, she only claimed to represent residents of her own public housing development. She also is more modest about her experience and what she knows, in sharp contrast to the activists: 
"I don't know about any other development, but my own. I had to climb 24 stories to my apartment after Sandy. Every single day with flashlights. So as long as you protect my development and we don't have to go through that again, the rest can be worked out. Protect us from the water, please."

Both RA presidents mentioned that flood protection from future storms is their priority, and that the "rest can be worked out." Contrast the language of representation used by RA presidents to language used by activists who oppose the plan. At a public meeting in early summer of 2019, a leader of East River Alliance, a newly formed group to protest the city's change of plans, occupied a dedicated slot to speak in front of a crowd after a presentation by city officials. The leader, a white woman, said: "[After the plan change] we stepped into the role of engaging a community that the city sold short - addressing concerns about the new plan... we've talked to a lot of people in the community and we're trying to understand different needs, different concerns." The language of "the community" is also ubiquitous in pamphlets and on the websites of groups opposing the plan. The East River Alliance, for example, calls itself a coalition of "community members" with the goal of engaging in collaborative processes between city agencies and the "community." Whom the community comprises remains undefined and the language obscures disagreements among neighborhood residents about preferences for flood protection.

In terms of basic demographics, while again mine is not a random sample, some common characteristics of activists who stood against the plan are worth noting. All of the activists I interviewed are over 50, and most were over 65, and they are primarily white, though several Puerto Rican activists have been high-profile critics of the new plan, and some were even tenants in public housing. People with these characteristics constituted almost the entirety of the vocal voices against the plan. Most activists I spoke to had come to the neighborhood as adults in the 1970's and 80's, and have been activists for decades. Greg, for example, a visible activist and organizer of some of the best-attended protests, moved to the East Village in the 1970 's and immediately became involved in the neighborhood's squatter movement Now he runs a community center with a focus on "social and environmental justice." Similarly, many other activists I spoke with worked in affordable housing nonprofits for the last two or three decades, and through the 2000's participated in organized efforts against what they identified as the rapid gentrification of the neighborhood. People who spoke in meetings supporting the plan were invariably of Puerto Rican descent or black, lived in public housing, and often held leadership positions in their housing developments.

In the years after the city's change of plans, activists and residents of public housing alike came to perceive race as an axis that organized opinions on the plan, but in different ways. For representatives of public housing, the city's plan constituted an essential form of protection against flooding for the "black and brown" "frontlines," and as described above, they contended that white residents in market housing had no authority to speak for them. City officials also highlighted the climate justice dimensions of the plan, arguing that they had prioritized the neighborhood for protection due to its high concentration of public housing where the majority of residents are people of color. Yet from the point of view of activists, city officials 
tactically used the issue of race to divide and conquer the neighborhood and push the plan through. Activists steadfastly maintained that their groups represented the whole community, including people of all races and ethnicities in the LES. When I asked activists about race, they resisted insinuations that older white residents formed the majority of participants in advocacy groups and highlighted the occasions when Latin American or Black residents had participated protests or events.

In the summer of 2019 I went to a meeting of a neighborhood group focused on emergency preparedness. As I sat at a table of five people during a breakout exercise, the conversation veered off topic and landed on the ESCR, as it often did. Two activists began discussing a recent local news article about the project, which quoted two people living in public housing who supported the city's plan. Val, an older black activist, and Danny, an older white activist, discussed the news article:

"Val: The problem with it, is that it somewhat divides the community. You have Baruch, Lillian Wald, Jacob Riis [public housing developments], mainly black and Puerto Rican, poor, who need flood protection.

Danny: Now they're telling us that if you oppose the plan you are racist, and if you are for it, you're not racist. How does that make sense?

Val: [Sarcastically] Yeah, the people that don't want it, are racist, that's how it is. The two people they quoted were Puerto Rican folks that live in Baruch and Jacob Riis, they said, 'I wanna be protected,' and that's why they quoted them. Danny: That was on purpose by the proponents by this plan. They want to create division."

Val and Danny's exchange tells us that from the point of view of some activists, city officials and the news media cynically deployed the issue of race to garner support for the plan. When asked about the sources of disagreements between people who supported the plan and those who oppose it, few activists acknowledged that disagreements revealed a genuine diversity of opinions. Rather, activists pointed at city agencies for sowing discord, racially or otherwise: "The city's doing very little building of the social fabric here," Nancy, a white older activist told me, "really the city has, I think done a really good job of separating us, creating mistrust..." After the city embarked on its four-year process of collaboration with residents, Nancy felt that city agencies did not build up the "social fabric" - highlighting how the late move to change plans undermined all of the previous efforts to generate solidarity and consensus in the neighborhood. Similarly, Greg, a high-profile white activist who runs a local youth engagement organization, told me: "Yeah, nobody wants to be flooded again, but people are like mislead. People have been misled to believe that this is really the only plan to save them." Greg went on to state that the city tries to "mush up people's thinking" about the issue.

Beyond the change of plans, activists repeatedly emphasized their present-day use of environmental amenities in the park and how the new plan would destroy these features. Specifically, activists focused on three types of amenities that the park provided and which the project would disrupt: The existing trees and animal habitats in the park; the use of the park for leisure and socializing; and access to a large composting facility which would have to be relocated during construction. A centerpiece of the activists' argument in opposition to the new plan was 
the destruction of 960 trees, which would be ripped out to fill the park with an additional eight to ten feet of dirt. Along with the trees, self-described citizen scientists performed a series of surveys of animal and insect species in the park, and argued that a few bird and pollinator insect species would lose their scarce habitat in Manhattan. The fierce defense of the trees and animal habitats in favor of long-term flood protection was described to me by an exasperated city planner as a form of "climate change denial." In general, activists also emphasized the potential deterioration of their health and social life as a result of the loss of their day-to-day leisure space. In large part, activists preferred the old plan because it achieved flood protection while maintaining the vegetation (even if eventually sea level rise and storms would destroy it). In the new plan, flood protection was not worth the tradeoff for them if it meant they would lose their trees and birds.

Explicit references to the environmental injustice of these effects is ubiquitous. As one commenter to the project's Environmental Review Statement put it: "Where is the environmental justice in depriving us of our heart and lungs, family park and open space for many years? The park is the neighborhood living room." As the coronavirus pandemic reached New York, activists emphasized East River Park's role as a crucial reprieve for residents who were otherwise encouraged to stay home, and that a long construction period would deprive them of this amenity. Activists were not willing to temporarily tradeoff the park for long-term flood protection. Finally, the park remodeling would require evicting and relocating a large composting facility located near the Williamsburg Bridge section of the park. At the time of writing, the city had not yet found an alternative site for the composting equipment, and members of East River Park Action had threatened to sue the city over the issue. "How can the city claim to care about sustainability and resiliency," a local resident asked during a Community Board Parks Committee meeting in late 2020, "and at the same time destroy a composting facility?"

It is possible to imagine three other potential motivations, unrelated to temporal scale, that activists might have for rejecting the plan. However, on careful examination, these alternative explanations do not stand up to scrutiny. First, one could imagine, for example, that activists in general live further inland than public housing residents, and so flooding is less likely to affect them, leading them to deprioritize flood protection. This is not the case, however, since the majority of the vocal activists I spoke to lived either in market housing near the shore, or in one of the many private apartment complexes that interlocked with public housing buildings on the shore. All experienced some degree of flood damage during Sandy. Danny, for example, quoted earlier in this article, lives in a co-op building near the water.

Second, since activists tend to be old, it is possible to imagine they do not care about climate change impacts in their neighborhood as much as younger public housing residents do, many with young families who plan to stay in the neighborhood long-term. After all, the lives of many activists might not go on long enough to see the worst impacts of climate change, and the squeeze on affordable housing in the LES means their children might not experience flooding in lower Manhattan either. But the activists, as self-identified political progressives, often talked about the importance of climate change. Specifically, they questioned the carbon emissions implications of the new plan. They would ask: How could the city claim to 
care about climate change if they were willing to remove almost a thousand carbon dioxide-sucking trees from a park, or approve a plan that kept carbon-spewing cars choking the FDR Drive? Third, activists could also be worried about the ESCR project affecting housing prices. It is true, as we have seen earlier in the article, that residents are concerned about a new public amenity further rising rents in the LES. But this issue existed in the previous iteration of the plan as well, and activists did not use this as a motivation to paralyze the plan.

Activists almost always emphasized their strong attachment to the existing park when rejecting the city's new plan. When I met Pat Arnow, founder of East River Park Action, on a hot and humid early summer morning in 2021, she walked me to her favorite elm tree in the park. We sat on a shaded bench and talked while enjoying a cool breeze from the river. The elm tree had suffered damage from Sandy's saltwater and was slated for destruction as part of the new plan, but in Pat's view the tree was on its way to making a full recovery. Pat, who is white and in her 60's, moved to the neighborhood in the early 2000's after living in the U.S. south for two decades, working as a photographer for a magazine in North Carolina and for a women's movement group in West Virginia. Before the city's change of plans, Pat did not involve herself much in local activism. When I asked her how she came to oppose the ESCR so fervently, she summarized: "This park is so great and it makes living here a wonderful experience. Without it, living here would be kind of a bummer." It was easy at that moment to empathize with the residents who would lose access to the park for years, even while understanding that flood protection is vitally needed. It was also easy to imagine that painful conflicts like this one in Manhattan would repeat themselves across the city and throughout coastal areas across the world.

\section{Discussion: participatory democracy, community representation, and climate change}

The controversies over the fate of East River Park are symbolically dense. The planning of the original park, funded by the New Deal's Works Progress Administration (Wye, 2020), commissioned by Robert Moses, and built by Mayor La Guardia's administration in 1939, made no attempts at a democratic process or public input. A New York Times (1939) article announcing the park's inauguration described how city agencies cleared local "slums," reclaimed land from the East River to expand Manhattan's buildable area, and strengthened the coastal edge with a new seawall. The public amenity and seawall represented a classic example of urban renewal and symbolized the hard mid-twentieth century modern division between city and water - between society and nature - with the assumption that the climate would remain stable forever and that the ocean would never encroach on the city. The death and damage from Superstorm Sandy painted a different image of the future and injected urgency into efforts to adapt to a changed climate. Now the debate over East River Park is a site to observe whether New York and cities like it around the world will reproduce their decision-making styles from the mid-twentieth century or take a different route altogether, and with what effects. 
The findings here show that the city began with intentions to use democratic principles to guide the design and planning of the complex infrastructure project and attempted to reimagine the urban coastline as a blurred and sponge-like interstitial zone between city and ocean. For a time, this process succeeded as an experiment in participatory design and participants were able to iteratively recognize their own input in architectural sketches and diagrams - they felt they were meaningfully influencing the planning process. Importantly, in the first phase of the project, participants were not anti-expert, as they cooperated with highly specialized professional landscape architects and were willing to work with the funding expectations that the city set for the project. However, the city found it impossible to go through with this approach. As the project crunched through the bureaucratic city procedures to review its engineering feasibility and turn the plan into a built reality, the city found that it could not deliver the design promises it had made. To defend its new plan, the city then retreated into a technocratic decision-making style, repeatedly appealing to the authority of objectivity in public demonstrations. Residents no longer saw their input reflected in city plans even as they remained involved contributors in the process, and rejected the city's plans as politically motivated and staff's technical expertise as tarnished by political associations. The result was a legitimacy crisis and local resistance in opposition to the plan. Another result was a bitter conflict among neighborhood residents - between those who valued a flawed plan that would still provide flood protection, and those who rejected the city's new decision-making style and the wholesale destruction of the park.

The contentious politics of inequality and class at play in the LES can be observed across the city, as controversy has emerged over a number of large-scale projects and city initiatives in recent years. The movement resisting the ESCR project can be compared to the 2018-2019 opposition to Amazon's proposal to build their second headquarters, "HQ2," in Long Island City, Queens. In 2018, New York's city government proposed a generous set of public subsidies to attract Amazon to the neighborhood in exchange for much-needed employment for nearby residents, a large portion of whom live in public housing by the coast. Some local representatives of public housing residents (overwhelmingly people of color) and local unions supported HQ2, but progressive residents across the city vocally resisted the proposal. The opponents of HQ2 plan were backed by a group of local politicians including Representative Alexandria Ocasio-Cortez. Due to overwhelming pressure, Amazon eventually withdrew their proposal (Goodman, 2019). There are substantive differences between the ESCR project and Amazon's HQ2 proposal. Amazon's facility, in theory, promised to provide employment for nearby residents, while the ESCR project aims to protect people from flooding and will not directly financially benefit residents. Additionally, progressive New Yorkers did not reject the Amazon HQ2 on because they use the Queens waterfront for recreation or for its environmental amenities. They resisted the proposal because they reject Amazon's practices as a business in general, citing cruel working conditions for employees and the potential erosion of the city's identity (Goodman, 2019).

There are also a few important theoretical commonalities between the cases. In both the ESCR and Amazon cases, the more affluent and white groups purported to speak for the entire relevant community. In the case of the ESCR, older activists 
in market housing claimed to speak for the entire LES, and claimed that it was in the interests of the entire community to reject the plan. If people disagreed and supported the plan, like public housing representatives did, these people had been manipulated by the city, at least in the eyes of activists. Similarly, in the Amazon HQ case, progressive city residents, typically more affluent white residents of Manhattan and Brooklyn, claimed to speak for the entire city's residents. In their eyes, all New Yorkers would suffer in the long term if Amazon's HQ settled in Queens, and if anyone disagreed, it was because they had been manipulated by Amazon's promises of jobs and economic growth in the city. In both the ESCR and Amazon HQ2 cases, progressive residents failed to acknowledge a genuine difference of interests, and assumed that if public housing residents disagreed with them, it was because they were being manipulated by outside forces. As a result, a rift emerged in both cases between groups who might otherwise have been on the same side of the issue. More affluent and white New Yorkers, as well as public housing residents, both claimed to value climate change planning and equitable economic development. Thus the creation of rifts obscured opportunities to build broader movement coalitions to pursue these common goals.

This study has at least one important limitation. The focus on a single project in one neighborhood precludes comparisons of how design and construction of climate infrastructure plays out across different neighborhoods. Analyzing how the envisioning of flood-protective infrastructure takes place in the Lower East Side compared to, for example, the financial district to the south or a more socially homogenouslyneighborhood in the city's outer boroughs, could reveal important patterns of how planning for climate infrastructure reproduces urban inequality. What level of protection from devastating flooding does the city provide in the financial district of Manhattan versus outer lying areas in the city? Who gets to have a voice in designing plans in the financial district versus a low-income Brooklyn or Queens neighborhood? Are the roles of the political constituencies identified here - property developers, activists, public housing residents, and city professionals - different across neighborhoods, and if so, howhow do these differences produce variations in plans? These questions, as Klinenberg et al. (2020) argue, are likely to form the heart of environmental justice research in the coming decades. The LES effectively shows conflicts over democracy, expertise, and representation, but broadening the scope to other climate infrastructure projects could reveal other important social dimensions.

Are the social controversies over democratic input identified here generalizable across other cities in the world? It is difficult to tell from ethnographic data, and unlikely that the details of the New York case speak to the precise reality in other cities. Yet the stark presence of the mechanisms producing the legitimacy crisis in New York is telling. There is reason to expect the social controversies arising from the ESCR may be exacerbated and not softened in cities pursuing large scaleclimate infrastructure: New York has pluralistic and participatory city politics, but even here, city officials ended up wielding authority by relying on technical expertise and ignoring the plan of public consensus. If and when governments of cities around the world begin pursuing similar projects to protect people living on the coast, it is possible that similar frictions could emerge between city and residents, as well as rifts between groups prioritizing existing environmental amenities and 
groups emphasizing long-term protection from climate impacts. Additional empirical research in other cities can shed light on these questions.

\section{Conclusion}

As a global scientific consensus warns of potential catastrophic impacts from climate change, social researchers interested in identifying the potential roles for citizens, scientists, and the state in crafting policy decisions will have to grapple with the tensions between participatory democracy and technical expertise. Decisions made through social consensus may not be technically feasible or fast, and on the flip side, decisions made solely through appeals to "mechanical objectivity" and expert judgement may find no political legitimacy and produce strong resistance. In the New York case we can see the legitimizing effects of a participatory process coupled with influence, that is, the ability of participants to recognize their own input reflected in plans. Without it, the state can produce for itself a legitimacy crisis and social conflict that cannot be resolved with any amount of appeals to objectivity or rationality. Importantly, residents of the Lower East Side were not inherently anti-expert throughout the process, but rather mobilized in resistance of the project once they felt they had lost the thread of influence on the plans and that their expectations had been subverted. This paper ultimately argues that solutions to complex problems will require political legitimacy gained through a public that can recognize their own influence on plans, as well as the input of technical experts necessary to arrive at feasible solutions within the time-frame demanded by the fast-approaching problem of climate change. This article does not provide a roadmap to achieve such legitimacy. I follow Eyal (2019) in arguing that "when it comes to public, political debate, the main contribution of [works of dry scholarship] cannot be to offer solutions, or to tell people what they ought to do." Rather, such scholarship, Weber (1946, quoted in Eyal, 2019) argues in his "Science as a Vocation" lecture, should force the different sides to "recognize inconvenient facts - I mean facts that are inconvenient for their party opinions."

Acknowledgments I have had the benefit of critical comments and encouragement from Eric Klinenberg, Gianpaolo Baiocchi, Paul DiMaggio, Ankit Bhardwaj, Hillary Angelo, Eric Blanc, two anonymous reviewers, and the editors at Theory and Society. I am also indebted to participants in the East Side Coastal Resiliency Project planning process for the voices that appear in this article.

Availability of data and material Data from planning documents, news media, and some public meetings are publicly available online.

Code availability Not applicable.

Authors' contributions The author conducted all research and writing.

Funding The funding that enabled this research comes from NYU's Department of Sociology and a Social Sciences and Humanities Research Council of Canada Doctoral Fellowship. 


\section{Declarations}

Conflicts of interest/competing interests Not applicable.

\section{References}

Agyeman, J., Schlosberg, D., Craven, L., \& Matthews, C. (2016). Trends and directions in environmental justice: From inequity to everyday life, community, and just sustainabilities. Annual Review of Environment and Resources, 41.

Alley, K. D., Faupel, C. E., \& Bailey, C. (1995). The historical transformation of a grassroots environmental group. Human Organization, 410-416.

Anguelovski, I., Shi, L., Chu, E., Gallagher, D., Goh, K., Lamb, Z., et al. (2016). Equity impacts of urban land use planning for climate adaptation: Critical perspectives from the global north and south. Journal of Planning Education and Research, 36(3), 333-348.

Araos, M., Berrang-Ford, L., Ford, J. D., Austin, S. E., Biesbroek, R., \& Lesnikowski, A. (2016). Climate change adaptation planning in large cities: A systematic global assessment. Environmental Science \& Policy, 66, 375-382.

Arnstein, S. R. (1969). A ladder of citizen participation. Journal of the American Institute of Planners, 35(4), 216-224.

Auyero, J., \& Swistun, D. (2008). The social production of toxic uncertainty. American Sociological Review, 73(3), 357-379.

Baiocchi, G., \& Ganuza, E. (2016). Popular democracy: The paradox of participation. Stanford University Press.

Beck, U. (1992). Risk society: Towards a new modernity. SAGE Publications.

Bourdieu, P. (1989). The corporatism of the universal: The role of intellectuals in the modern world. Telos, 1989(81), 99-110.

Brash, J. (2011). Bloomberg's New York: Class and governance in the luxury city (Vol. 6). University of Georgia Press.

Bullard, R. D. (2018). Dumping in Dixie: Race, class, and environmental quality. Routledge.

Callon, M., Lascoumes, P., \& Barthe, Y. (2009). Acting in an uncertain world: An essay on technical democracy. MIT Press.

Checker, M. (2004). “We all have identity at the table": Negotiating difference in a southern African American environmental justice network. Identities: Global Studies in Culture and Power, 11(2), 171-194.

Ciplet, D., Roberts, J. T., \& Khan, M. R. (2015). Power in a warming world: The new global politics of climate change and the remaking of environmental inequality. MIT Press.

City of New York Office of Budget and Management. (2018). Value Engineering Study - East Side Coastal Resiliency Project. https://www1.nyc.gov/assets/escr/downloads/pdf/escr_value_engin eering_study_preliminary_report_2018.pdf.

Collier, S. J., Cox, S., \& Grove, K. (2016). Rebuilding by Design in Post-Sandy New York. Limn. https:// limn.it/articles/rebuilding-by-design-in-post-sandy-new-york/. Accessed 24 Nov 2019.

de Sherbinin, A., \& Bardy, G. (2015). Social vulnerability to floods in two coastal megacities: New York City and Mumbai. Vienna Yearbook of Population Research, 13, 131-165.

Dewey, J. (1927). The Public and Its Problems (Vol. 1954). Swallow Press.

DuPuis, E. M., \& Greenberg, M. (2019). The right to the resilient city: Progressive politics and the green growth machine in new York City. Journal of Environmental Studies and Sciences, 9, 352-363.

Easterly, W. (2014). The tyranny of experts: Economists, dictators, and the forgotten rights of the poor. Basic Books.

Erikson, K. T. (1976). Everything in its path. Simon and Schuster.

Eyal, G. (2019). The crisis of expertise. Polity Press.

Fan, M. (2016). Environmental justice and the politics of risk: Water resource controversies in Taiwan. Human Ecology, 44(4), 425-434.

Fleming, B. (2019). Design and the Green new Deal. Places Journal. https://doi.org/10.22269/190416.

Foucault, M. (1980). Power/knowledge: Selected interviews and other writings, 1972-1977. Pantheon Books. 
Futrell, R. (2003). Technical adversarialism and participatory collaboration in the US chemical weapons disposal program. Science, Technology, \& Human Values, 28(4), 451-482.

Georgeson, L., Maslin, M., Poessinouw, M., \& Howard, S. (2016). Adaptation responses to climate change differ between global megacities. Nature Climate Change, 6(6), 584-588.

Golan, T. (2004). Laws of men and laws of nature. Harvard University Press.

Goodell, J. (2016). Can New York be saved in the era of global warming? Rolling Stone. https://www.rolli ngstone.com/culture/culture-news/can-new-york-be-saved-in-the-era-of-global-warming-240454/. Accessed 31 May 2020.

Goodman, J. D. (2019). Amazon Pulls Out of Planned New York City Headquarters. The New York Times. https://www.nytimes.com/2019/02/14/nyregion/amazon-hq2-queens.html. Accessed 28 Apr 2021.

Gould, K. A., \& Lewis, T. L. (2018). From Green gentrification to resilience gentrification: An example from Brooklyn 1. City \& Community, 17(1), 12-15.

Graham, L., Debucquoy, W., \& Anguelovski, I. (2016). The influence of urban development dynamics on community resilience practice in new York City after superstorm Sandy: Experiences from the lower east side and the rockaways. Global Environmental Change, 40, 112-124.

Green, K. E., \& Lund, J. F. (2015). The politics of expertise in participatory forestry: A case from Tanzania. Forest Policy and Economics, 60, 27-34. https://doi.org/10.1016/j.forpol.2014.11.012

Habermas, J. (1974). The public sphere: An encyclopedia article. New German Critique, 3, 49-55.

Harlan, S. L., Pellow, D. N., Roberts, J. T., Bell, S. E., Holt, W. G., \& Nagel, J. (2015). Climate justice and inequality. Climate change and society: Sociological perspectives, 127-163.

Heilbroner, R. (1974). An inquiry into the human Prospect. Norton.

Held, D., \& Hervey, A. (2013). Democracy, climate change and global governance: Democratic agency and the policy menu ahead. InThe governance of climate change (pp. 89-110). Polity Press.

Hino, M., Field, C. B., \& Mach, K. J. (2017). Managed retreat as a response to natural hazard risk. Nature Climate Change, 7(5), 364-370.

IPCC. (2018). Summary for policymakers. In global warming of $1.5^{\circ} \mathrm{C}$. an IPCC special report on the impacts of global warming of $1.5^{\circ} \mathrm{C}$ above pre-industrial levels and related global greenhouse gas emission pathways, in the context of strengthening the global response to the threat of climate change, sustainable development, and efforts to eradicate poverty. Geneva: World Meteorological Organization. https://www.ipcc.ch/sr15/chapter/summary-for-policy-makers/. Accessed 5 Apr 2019.

Jerolmack, C., \& Murphy, A. K. (2019). The ethical dilemmas and social scientific trade-offs of masking in ethnography. Sociological Methods \& Research, 48(4), 801-827.

Jerolmack, C., \& Walker, E. T. (2018). Please in my backyard: Quiet mobilization in support of fracking in an Appalachian community. American Journal of Sociology, 124(2), 479-516.

Keenan, J. M., Hill, T., \& Gumber, A. (2018). Climate gentrification: From theory to empiricism in Miami-Dade County, Florida. Environmental Research Letters, 13(5). https://doi.org/10.1088/17489326/aabb32.

Kimmelman, M. (2019). Essex Crossing Is the Anti-Hudson Yards. The New York Times. https://www. nytimes.com/2019/11/07/arts/design/essex-crossing.html. Accessed 27 Apr 2021.

Klinenberg, E. (1999). Denaturalizing disaster: A social autopsy of the 1995 Chicago heat wave. Theory and Society, 28(2), 239-295.

Klinenberg, E. (2018). Palaces for the people: How social infrastructure can help fight inequality, polarization, and the decline of civic life. Broadway Books.

Klinenberg, E., Araos, M., \& Koslov, L. (2020). Sociology and the climate crisis. Annual Review of Sociology, 46. https://doi.org/10.1146/annurev-soc-121919-054750.

Koslov, L. (2016). The case for retreat. Public culture, 28(2 79), 359-387.

Kulp, S. A., \& Strauss, B. H. (2019). New elevation data triple estimates of global vulnerability to sealevel rise and coastal flooding. Nature Communications, 10(1), 4844. https://doi.org/10.1038/ s41467-019-12808-Z

Lakoff, A., \& Klinenberg, E. (2010). Of risk and pork: Urban security and the politics of objectivity. Theory and Society, 39(5), 503-525.

Levine, J. R. (2017). The paradox of community power: Cultural processes and elite authority in participatory governance. Social Forces, 95(3), 1155-1179.

Li, Y., \& Zhong, X. (2020). 'For the People'Without 'by the people': People and plans in Shanghai's waterfront development. International Journal of Urban and Regional Research.

Lippmann, W. (1922). Public opinion. McMillan. 
Maskovsky, J. (2006). Governing the "new hometowns": Race, power, and neighborhood participation in the new inner city. Identities: Global Studies in Culture and Power, 13(1), 73-99.

Mauss, M. (1985). A category of the human mind: The notion of person; the notion of self. InThe category of the person: Anthropology, philosophy, history (pp. 1-25). Cambridge University Press.

McQuarrie, M. (2013). No contest: Participatory technologies and the transformation of urban authority. Public culture, 25(1: 69), 143-175.

Millner, N., Peñagaricano, I., Fernandez, M., \& Snook, L. K. (2020). The politics of participation: Negotiating relationships through community forestry in the Maya biosphere reserve, Guatemala. World Development, 127, 104743.

Molotch, H. (1970). Oil in Santa Barbara and power in America. Sociological Inquiry, 40(1), 131-144.

Moynihan, D. P. (1969). Maximum feasible misunderstanding: Community action in the war on poverty. University of Michigan Press.

Murphy, A. K., Jerolmack, C., \& Smith, D. (2021). Ethnography, data transparency, and the information age. Annual Review of Sociology, 47.

Navon, D., \& Eyal, G. (2016). Looping genomes: Diagnostic change and the genetic makeup of the autism population. American Journal of Sociology, 121(5), 1416-1471.

New York City Mayor's Office. (2019). OneNYC 2050: New York City's Strategic Plan. https://onenyc. cityofnewyork.us/.

New York Times. (1939). EAST RIVER PARK WILL OPEN TODAY; area transforming waterfront slums into recreational development Ready. The New York Times. https://www.nytimes.com/1939/ 07/27/archives/east-river-park-will-open-today-area-transforming-waterfront-slums.html. Accessed 24 Jul 2020

Ngu, S. (2019). Will luxury towers edge out the last of the working-class Chinese in New York's iconic Chinatown? Vox. https://www.vox.com/the-highlight/2019/9/18/20861446/new-york-city-china town-gentrification-lower-east-side. Accessed 27 Apr 2021

NYC Parks and Budget Office. (2019). Chapter 10.0: Response to comments on the DEIS. In environmental review - the east side coastal resiliency project. https://www1.nyc.gov/assets/escr/downl oads/pdf/FEIS/ESCR-EIS-Chapter-10.0-Response-to-Comments-on-the-DEIS.pdf. Accessed 25 Nov 2019.

NYU Furman Center. (2018). State of New York City's Housing and Neighborhoods in 2018. https:// furmancenter.org/files/sotc/SOC_2018_PART2_New_York_City.pdf.

Ophuls, W. (1977). Ecology and the politics of scarcity. Freeman.

Oppenheimer, M., Glavovich, B. C., Hinkel, J., van de Wal, R., Magnan, A., Abd-Elgawad, R., et al. (2019). Sea level rise and implications for low-Lying Islands, Coasts and Communities. In IPCC Special Report on the Ocean and Cryosphere in a Changing Climate. https://www.ipcc.ch/srocc/ chapter/chapter-4-sea-level-rise-and-implications-for-low-lying-islands-coasts-and-communities/. Accessed 24 Nov 2019.

Oreskes, N., \& Conway, E. M. (2011). Merchants of doubt: How a handful of scientists obscured the truth on issues from tobacco smoke to global warming. Bloomsbury USA.

Ottinger, G. (2013). Changing knowledge, local knowledge, and knowledge gaps: STS insights into procedural justice. Science, Technology, \& Human Values, 38(2), 250-270.

Pacewicz, J. (2020). What can you do with a single case? How to Think About Ethnographic Case Selection Like a Historical Sociologist. Sociological Methods \& Research. https://doi.org/10.1177/00491 24119901213.

Park, R. E. (1915). The city: Suggestions for the investigation of human behavior in the city environment. American Journal of Sociology, 20(5), 577-612.

Pickering, J., Bäckstrand, K., \& Schlosberg, D. (2020). Between environmental and ecological democracy: Theory and practice at the democracy-environment nexus. Taylor \& Francis.

Porter, T. M. (1996). Trust in numbers: The pursuit of objectivity in science and public life. Princeton University Press.

Putnam, R. D. (2000). Bowling alone: The collapse and revival of American community. Simon and Schuster.

Rice, J. L., Cohen, D. A., Long, J., \& Jurjevich, J. R. (2019). Contradictions of the climate-friendly New Perspectives on Eco-Gentrification and Housing Justice. International Journal of Urban and Regional Research. https://doi.org/10.1111/1468-2427.12740.

Roberts, J. T., \& Parks, B. (2006). A climate of injustice: Global inequality, north-south politics, and climate policy. MIT press. 
Schlosberg, D., \& Collins, L. B. (2014). From environmental to climate justice: Climate change and the discourse of environmental justice. Wiley Interdisciplinary Reviews: Climate Change, 5(3), 359-374.

Schmeltz, M. T., González, S. K., Fuentes, L., Kwan, A., Ortega-Williams, A., \& Cowan, L. P. (2013). Lessons from hurricane Sandy: A community response in Brooklyn, New York. Journal of Urban Health, 90(5), 799-809. https://doi.org/10.1007/s11524-013-9832-9

Schudson, M. (1999). The good citizen: A history of American civic life. Harvard University Press.

Schudson, M. (2006). The trouble with experts-and why democracies need them. Theory and Society, 35(5-6), 491-506.

Selznick, P. (1953). TVA and the grass roots: A study in the sociology of formal organization. University of California Press.

Shi, L., Chu, E., Anguelovski, I., Aylett, A., Debats, J., Goh, K., et al. (2016). Roadmap towards justice in urban climate adaptation research. Nature Climate Change, 6(2), 131-131.

Siders, A. (2019). Social justice implications of US managed retreat buyout programs. Climatic Change, 152(2), 239-257.

Taylor, D. E. (2000). The rise of the environmental justice paradigm: Injustice framing and the social construction of environmental discourses. American Behavioral Scientist, 43(4), 508-580.

Taylor, D. E. (2009). The environment and the people in American cities, 1600s-1900s: Disorder, inequality, and social change. Duke University Press.

Taylor, D. E. (2016). The rise of the American conservation movement: Power, privilege, and environmental protection. Duke University Press.

Wachsmuth, D., Cohen, D. A., \& Angelo, H. (2016). Expand the frontiers of urban sustainability. Nature News, 536(7617), 391.

Walker, E. T., McQuarrie, M., \& Lee, C. W. (2015). Rising participation and declining democracy. InDemocratizing inequalities: Dilemmas of the new public participation (pp. 3-23). NYU Press.

Weber, M. (1946). Science as a vocation. Inscience and the quest for reality (pp. 382-394). Springer.

Weber, M. (2004). The essential Weber: A reader. Routledge.

Wye, D. (2020). Threatened East River Park buildings recognized for architectural distinction. Bowery Boogie. https://www.boweryboogie.com/2020/07/threatened-east-river-park-buildings-recognizedfor-architectural-distinction/. Accessed 24 Jul 2020.

Zussman, R. (2004). People in places. Qualitative Sociology, 27(4), 351-363.

Publisher's note Springer Nature remains neutral with regard to jurisdictional claims in published maps and institutional affiliations.

Malcolm Araos is a PhD Candidate in the Department of Sociology at New York University and a Fellow at NYU's Institute for Public Knowledge. 